\title{
特発性脊髄くも膜下，硬膜外血腫の一例
}

$\begin{array}{clll}\text { 水島中央病院整形外科 } & & & \\ \text { 井 上 } & \text { 周 - 藤 原 紘 郎 } \\ \text { 光 田 昌 } & \text { 弘・越 智 信 夫 } \\ \text { 竜操整形外科病院 } & & & \\ \text { 今 井 } & \text { 健 } & & \end{array}$

\section{A Case Report of Spontaneous Spinal Subarachnoid and Epidural Hematoma}

by

\section{Meguru Inoue, Hiroo Fujiwara, Masahiro Mitsuda and Nobuo Ochi}

Department of Orthopedic Surgery, Mizushima Central Hospital, Okayama

\section{Ken Imai}

Ryuso Orthopedic Hospital, Okayama

\begin{abstract}
A rare case of spontaneous spinal subarachnoid and epidural hematoma who had surgical treatment and fair recovery was reported. A 48-year-old male complained of sudden and severe upper back pain at the onset, and developed paraplegia. A lumbar puncture revealed bloody cerebrospinal fluid, and myelography showed complete block at the level of L1. A cisternal puncture failed but peridrography was obtained. It showed blockage at the level of C4. CT scan showed high density area at the ventral side of the upper thoracic spinal canal. Operation was performed 15 hours after paraplegia. Laminectomy from C7 to L1 showed normal looking but nonpulsatile dural tube. On opening the dura and arachnoid membrane, clots were found on the ventral side extending from C7 to T11. No specific bleeding point was identified.

At present, five months after surgery, he can walk with two crutches, but muscle weakness and sensory disturbance remain.
\end{abstract}

はじめに

脊髄くも膜下血腫および硬膜外血腫はまれな疾患で ある. 今回われわれは誘因なく, 突然の後頸部, 上背 部痛より発症, 手術を施行し, くも膜下および硬膜外 に血腫を確認した 1 例を経験したので報告する.

\section{症例}

症例：48才, 男性, 会社経営.

主訴：後頸部, 上背部痛.

家族歴・既応歴：特記すべきことなし．
現病歴：昭和 62 年 6 月 19 日誘因なく後頸部, 上背 部痛が出現した。 6 月 21 日当院初診, X-P, 神経学的 異常所見なく，湿布，消炎鎮痛剂投与にて疼痛軽減す るも鈍痛は持続していた。 6 月 26 日夕, 仕事中頸部を ねじってょり急に後頸部, 上背部に激痛出現し, 当院 救急外来受診。上下肢に運動障害なく歩行可能であっ たが, 疼痛は激しくのたうちまわる状態であり, 大量 の鎮痛剂を使用し入院した. 6 月 27 日午前 0 時頃両下 肢の自動運動不能に気づく.

6 月 27 日朝の現症は, 意識, 両上肢正常, 疼痛は軽 減しているが，両下肢完全運動麻痺あり。乳頭部以下 
の温, 痛覚脱出あるが触覚は保たれていた。膝蓋腱, アキレス腱反射低下し，Babinski 反射, Ankle clonus が左側で陽性であった。膀腅直腸障害もあった。

検查所見：検血，検尿，肝機能検查など異常なく， 出血，凝固時間も正常範囲であった。腰椎穿刺による

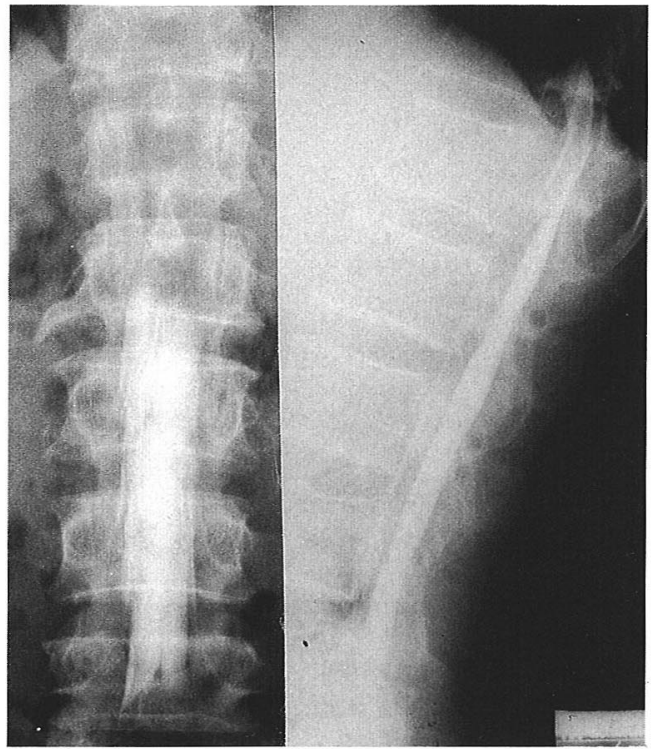

図 1 上行性ミエログラフィー $\mathrm{L}_{1}$ で block 像を認めた。脊柱管腔腹側に造影剂 が充満しなかった。

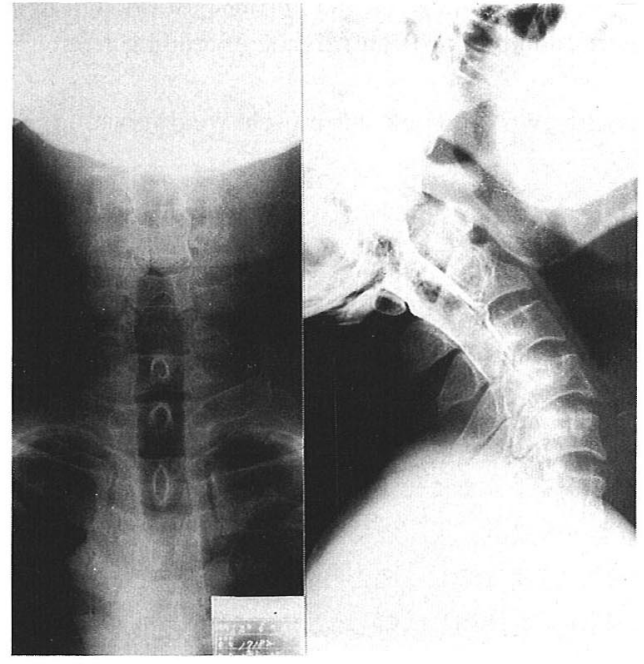

図2 下行性ミエログラフィー

硬膜外造影となったが, $\mathrm{C}_{4}$ 以下には下行しなか った.
髄液の性状はやや粘調な血性であり, Nonne-Apelt, Pandy 強陽性, 細胞数 $1968 / 3$, 蛋白 $1,000 \mathrm{mg} / \mathrm{dl}$ と上 昇していた。

腰椎よりの上行性ミエログラフィーでは, $\mathrm{L}_{1}$ で閉鎖 像を示し, 側面像で腰椎部の脊柱管腔の腹側に造影剂 の充満しない部を認めた (図 1 )。後頭窩穿刺による下 行性ミエログラフィーは困難であり，硬膜外造影とな ったが $\mathrm{C}_{4}$ 以下には造影剤は下行しなかった（図2）。 $\mathrm{CT}$ では $\mathrm{T}_{1}$ 以下の上部胸椎部で脊柱管腔腹側部に high-density area を認めた（図 3 ).

手術所見：6月 27 日午後 3 時, すなわち, 麻痺出現 より約 15 時間後より脊柱管内の出血, $\mathrm{A}-\mathrm{V}$ malformationなどを疑って手術施行した。臨床症状, ミエログ ラフィー， $\mathrm{CT}$ 像より判断し，まず $\mathrm{C}_{7}$ から $\mathrm{T}_{2}$ まで Laminectomy を行った. 硬膜に拍動なく, 色調も正常 であった，硬膜，くも膜を切開し泰䯣を露出するも䯣 液の漏出なく,脊髄はやや膨隆ぎみであった(図 $4 \mathrm{a}$ ). 脊髄の緊張が強いため両側 $T_{2}$ root を切離し, 脊䯣を

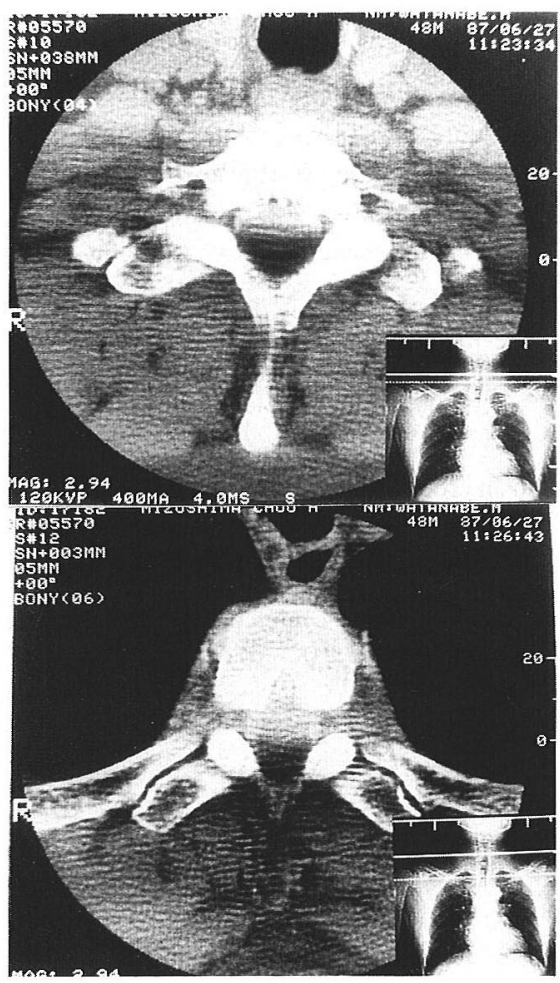

図 3 CT 像

上部胸椎部で脊椎管腹側に high-density area を認めた。 
retract すると前方のくも膜下腔に黒色の凝血塊を認め 除去した (図 4 b)）この部には硬膜外腔腹側にも少量 の凝血塊が認められ除去した (図 $4 \mathrm{c}$ )。脊䯣腹側の血 腫は胸椎末梢にも連続しみられたため, Laminectomy を $\mathrm{L}_{1}$ まですすめた。血腫は $\mathrm{T}_{11}$ レベルまで認められ除 去した。肉眼的には出血部位は確認できず，血管異常 なども認められなかった。図 5 は摘出された血腫の一 部である。

術後経過：術後 1 週間で右下肢自動運動出現， 5 週 間後左下肢自動運動出現し，自尿も見られ始めた。筋 力は徐々に増強し, 術後 5 力月の現在, 温, 痛覚鈍麻,

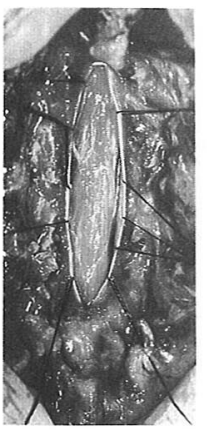

a

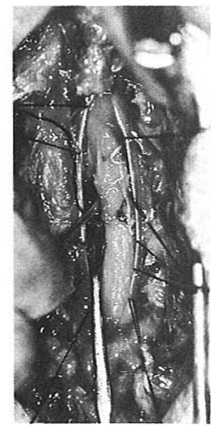

$\mathrm{b}$

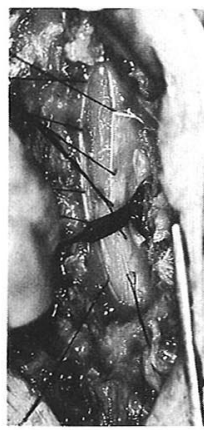

c

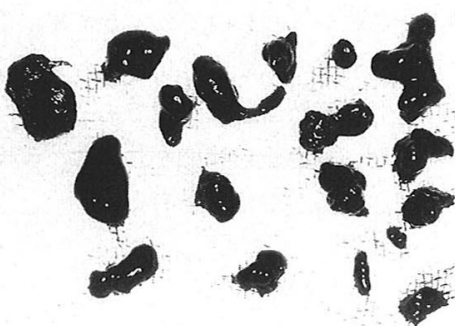

図 5 摘出された血腫の一部

b : 脊髄腹側に血腫を認める。
両下肢の筋力低下残存し，痙性はあるが 2 本松葉杖て の歩行が可能である。

考察

脊柱管内血腫はまれな疾患であるが，その中でも硬 膜外に血腫がみられる頻度が高く, 硬膜下，くも膜下 血腫は非常にまれである。硬膜外腔は脂肪組織と豊富 な傍椎体静脈叢で占められておうり，この血管が破綻す ることにより血腫を形成することがあるが1), 硬膜内に は頭蓋内における脳表面と上矢状洞間を走る架橋静脈 のような硬膜下腔を横断する血管は存在しないことが， 血腫が発生しにくい大きな理由であるといわれている゙!.

c：硬膜外腔腹側にも血腫を認める。

表 1 脊髄硬膜下，〈も膜下血腫本邦報告例

\begin{tabular}{|c|c|c|c|c|c|c|c|}
\hline 報＼cjkstart告 & 者 & 報告年 & 年 令 & 性 & 高 位 & 誘 因 & 予 後 \\
\hline 稀 & 代 & 1964 & 6 & 우 & $?$ & $(-)$ & 治 瘾 \\
\hline 池 & 田 & 1971 & 33 & 우 & $\mathrm{T}_{11} \sim \mathrm{T}_{12}$ & $(-)$ & 治 瘾 \\
\hline 斉 & 藤 & 1975 & 46 & $\sigma^{7}$ & $\mathrm{C}_{5}$ & $\mathrm{C}_{5}-6$ 脱臼 & 不 変 \\
\hline 西 & 山 & 1980 & 30 & 우 & $\mathrm{L}_{1} \sim \mathrm{L}_{4}$ & 妊娠 中毒症 & 軽 快 \\
\hline 安 & 田 & 1983 & 31 & $\sigma^{7}$ & $\begin{array}{l}\mathrm{T}_{8} \sim \mathrm{T}_{10}, \quad \mathrm{~L}_{1} \\
\mathrm{~L}_{5} \sim \mathrm{S}_{1}\end{array}$ & 白 血 病 & 死亡 \\
\hline 森 & & 1985 & 43 & $\sigma^{\pi}$ & $\mathrm{C}_{1} \sim \mathrm{C}_{3}$ & 外傷 & 軽 快 \\
\hline 宝 & 金 & 1985 & 9 力月 & $\sigma^{7}$ & $\mathrm{~T}_{8} \sim \mathrm{S}$ & 血友病 $\mathrm{A}$ & 軽 快 \\
\hline 武 & 田 & 1985 & 未熟児 & 우 & $\mathrm{T}_{10} \sim \mathrm{L}_{5}$ & 腰 椎 穿 刺 & 軽 快 \\
\hline 大 & 野 & 1985 & 51 & 우 & $\mathrm{T}_{4} \sim \mathrm{L}_{4}$ & 腰 椎 穿 刺 & 不 変 \\
\hline 長 谷 & 川 & 1985 & 52 & $\sigma^{x}$ & $\mathrm{~T}_{8} \sim \mathrm{L}_{4}$ & 腰 椎 穿 刺 & 軽 快 \\
\hline 井 & 上 & 1987 & 48 & $\sigma^{7}$ & $\mathrm{C}_{7} \sim \mathrm{T}_{11}$ & $(-)$ & 軽 快 \\
\hline
\end{tabular}


また，Russel1 ${ }^{5)}$ はくも膜下腔には髄夜が存在するため 血腫が形成されにくく，大量の出血があり髄液の流れ が blockされたとき血腫が形成されるであろうと述心゙ ている.本症例に扔いても血腫は $\mathrm{C}_{7}$ から $\mathrm{T}_{11}$ までと広 範にわたっており大量の出血が予想される．本邦での 脊髄硬膜内（硬膜下，〈も膜下）の血腫は 10 例の報告 があるのみである。そのうちくも膜下血腫は 2 例であ $ろ^{2 \text { 24) }}$ (表 1 ).

出血の原因, 誘因としては外傷, 血管異常（奇形, 血管腫，腫瘍など)，出血傾向 (白血病，血友病など), 抗凝固療法中, 腰椎穿刺など報告されているが，本症 例では基礎疾患，誘因なく特発性と考える。

また，出血源についてはいずれの報告にもはっきり した記載はなく,本症例においても確認できなかった。 しかし, 上部胸椎部に血腫が多く, 脊髄圧迫も強く, 硬膜外にも血腫がみられたことより, 出血部は上部胸 椎部であり, 麻㾇の主原因もこの部と考元る. 硬膜外 にも血腫の見られた原因は不明である.

治療は早期に脊髄圧迫状態を診断し, 緊急に血腫除 去し，除圧することが必要と考える.

\section{ま と め}

1. 胸椎部に発生した特発性脊䯣くも膜下, 硬膜外 血腫の 1 症例について報告した。

2. 急激な背部痛ののち, 両下肢運動, 知覚麻痺が 出現したが, 早期に血腫除去し症状の改善がみられた。

3. 脊柱管内血腫では，早期に診断し，早期に血腫 除去するのが最善の治療と考える.

\section{参 考 文 献}

1) Edelson, R. N. et al. : Spinal subdural Hematoma complicating lumbar puncture: Occurrence in thrombocytepenic patients. Arch. Neurol., 31 : 134137, 1974.

2）森宏・他：Brown-Sequard 症候群を呈し, 診断 に Plain CT が有用であった外傷性脊㵦くも膜下血腫の 1 例. 富山県立中央病院医学雑誌, $9: 15-20,1985$.

3）西山和男·他：妊娠末期に発生した脊髄硬膜下血腫の 1 例. 整形外科, $33: 450-455,1982$.

4）大野博史・他：腰椎穿刺後に発症し, 対麻疩に至った 脊檤くも膜下血腫の 1 例. 中部整災会雑誌, $28: 1169-$ 1170, 1985.

5) Russell, N. A. et al. : Spinal subdural hematoma : A review. Swg. Neurol., 20 : 133-137, 1983. 